\title{
Lessons in Art and Architecture from the Qur'anic Surah al-Shu'ara' (the Poets)
}

\author{
SPAHIC OMER \\ Kuliyyah of Islamic Revealed Knowledge and Human Sciences, International Islamic University \\ Malaysia, P.O. Box 10, 50728 Kuala Lumpur, Malaysia \\ spahico@yahoo.com
}

Published online: 15 May 2019

To cite this article: Omer, S. 2019. Lessons in art and architecture from the Qur'anic surah al-Shu'ara' (the Poets). KEMANUSIAAN the Asian Journal of Humanities 26(1): 113-141, https://doi.org/10.21315/kajh2019.26.1.5

To link to this article: https://doi.org/10.21315/kajh2019.26.1.5

\begin{abstract}
This paper discusses the lessons in art and architecture in the Qur'anic chapter, or surah, al-Shu'ara' (the Poets). The discussion shows that poetry as an art cannot be equated with a divine revelation, nor can poets and their followers with Prophet Muhammad (pbuh) and his followers. Architecture as a noble enterprise is likewise not to be employed as a sign of leading a life of depravity and extravagance in luxury and self-indulgence. Instead, it is to be used for cultivating virtue and for pursuing a greater and more authentic and sustainable good. Poetry and architecture should be developed and dealt with as signs (ayat), testifying to the greatness and benevolence of the Creator and Master of all creation. They are to function as such inspired and guided by the signs of revelation and amidst the innumerable signs of creation. The paper presents the cases of art and architecture as per the content of surah al-Shu'ara', regarding them as human-made signs.
\end{abstract}

Keywords and phrases: poetry, art, architecture, surah al-Shu'ara', signs (ayat)

\section{Introduction}

Art is broadly defined as the conscious expression or application of skill and imagination in the production of items and experiences in order to be contemplated and appreciated for their beauty or emotional power (Adajian 2005). However, the definition is far from agreed upon. The debate on comprehensively defining art is raging (Adajian 2012). It covers both the "intensional", or connotative, and "extensional", or denotative definitions. That is partly the offshoot of the ongoing debate on research in art, encompassing elements of philosophy, especially epistemology and methodology, and educational politics and strategies (Borgdorff 2006). As a diverse range of human pursuits, art entails the creation of visual, auditory and performing artefacts or artworks. Literature, including poetry, prose,

(C) Penerbit Universiti Sains Malaysia, 2019. This work is licensed under the terms of the Creative Commons Attribution (CC BY) (http://creativecommons.org/licenses/by/4.0/). 
drama and performing arts, is categorised as one of the main components of art. Semantically, the term "art" is used as an abstract quality, whereas "the arts" imply an aggregate of artistic activities or works of art. Both terms can be used interchangeably, but with a full awareness of their subtle differences.

Architecture, on the other hand, is generally understood as the art and science of design and construction of buildings and landscapes for human inhabitation. In this interpretation, reason, science and art, process and place, and human intention are included (Wasserman, Sullivan and Palermo 2000). Architecture is more than buildings. It is about facilitating the human behaviour, solving everyday problems and making people's lives better and more meaningful. As a collaborative process, architecture reflects the way people live. It shows who people are and what they want to achieve in life. It is the identity of their culture and the quintessence of their civilisational consciousness and achievements.

However, whether architecture is art or science, or both, remains a contentious subject. To some, like Georg Wilhelm Friedrich Hegel and Richard Meier, architecture is the mother of all arts, or the greatest of the arts. It is autonomous and inclusive of all other fields (Hosey 2016; Fields 2000). But to others, like Lance Hosey and Patrik Schumacher, Zaha Hadid's partner, it is not (Hosey 2016). What is more, to the proponents of the latter view, regarding architecture as a form of art is not only misleading to the public, but also potentially damaging to society.

It seems, nevertheless, that the truth lies somewhere in between. According to Ken Boroson (2016), architecture is both art and science. They forge a constructive and reciprocal relationship. "The balanced integration of artistic sensibility and scientific methodology as it applies to designing buildings and their environments is essential to creating great architecture" (Boroson 2016). At any rate, it stands to reason that the debates on the definitions, scopes and characters of art and architecture resonate the depth and complexity of some outstanding issues and concerns that date back to approximately the 17 th century when art referred to any skill or mastery and was not differentiated from crafts or sciences.

Art and architecture are intrinsic to human consciousness and behaviour. They make humans human. Human existence on earth and forms of art and architecture, regardless of their sophistication and flair, are inseparable. They complement each other. The existence of one cannot be conceived without the existence of the other (Izetbegovic 1988; Lamya' 1985; al-Faruqi 1995). 
Ibn Khaldun (1967) rightly observed that building is a basis of civilization and is of the most indispensable crafts which man ought to gain knowledge of:

This (architecture or creating built environments) is the first and oldest craft of sedentary civilization. It is the knowledge of how to go about using houses and mansions for cover and shelter. This is because man has the natural disposition to reflect upon the outcome of things. Thus, it is unavoidable that he must reflect upon how to avert the harm arising from heat and cold by using houses which have walls and roofs to intervene between him and those things on all sides. This natural disposition to think, which is the real meaning of humanity, exists among (men) in different degrees.

Le Corbusier (1989) also remarked:

Architecture is one of the most urgent needs of man, for the house has always been the indispensable and first tool that he has forged for himself. Man's stock of tools marks out the stages of civilization, the Stone Age, the Bronze Age, the Iron Age. Tools are the result of successive improvement; the effort of all generations is embodied in them. The tool is the direct and immediate expression of progress; it gives man essential assistance and essential freedom also.

This paper discusses the lessons in art and architecture from the Qur'anic surah al-Shu'ara'. The lessons revolve around the thrusts of poetry as a form of literary art which uses aesthetic and rhythmic qualities of language to evoke meanings, architecture as a framework or physical locus of human culture and civilisation, and the idea of creating and reading art and architecture as signs. The paper demonstrates the importance of the Qur'an and Prophet Muhammad's (pbuh) Sunnah - the latter being the exemplary and ideal life pattern to be followed by Muslims - in formulating the authentic and comprehensive theories as well as ethics of Islamic art and architecture. It also demonstrates the close relationship between art and architecture and at what conceptual and corporeal junctures they converge, functioning as embodiments and signs of a higher metaphysical mandate. The Qur'an and Sunnah play the role of a conceptual foundation for Islamic art and architecture. Their part in shaping the identity of Islamic art and architecture can be summarised in the following concepts: education, guidance, inspiration, thrust and point of reference.

The lessons in question are divinely given. They are general, enduring and constant, in that they function as the embodiment of some constant and enduring existential values and principles. Needless to say that the lessons must be applied and their impact witnessed in the real world which is full of challenges and obstructions. 
They cannot remain in the orb of abstract concepts and recommendations. The application of the lessons signifies an amalgamation of the said values and principles, which are transcendental, with the fluctuating physical factors and features, which are related to the time and space dynamics as well as the variable human intellectual and creative capacities. In other words, the lessons' application connotes the integration between the spiritual and physical realms, and between the heavens and the earth. Indeed, such a modus represents the highest degree of Islamic artistic and architectural creativity.

\section{Main Themes of Surah al-Shu'ara'}

Surah al-Shu'ara' is the 26th surah in the Qur'an. It has 227 verses (ayat) which are divided into 11 sections. It was revealed in the middle Makkah period, about six to seven years before the migration (hijrah) to Madinah. It was revealed when, according to Ali (1990), the contact of the light of Islam and Prophet Muhammad's (pbuh) prophethood with the milieu of polytheist and pagan Makkah was testing the Makkans in their most arrogant mood. The surah is so called after the keyword, al-shu'ara' (the poets) in verse 224.

The salient recurring theme of the surah is that the conflict between the truth (haqq) and falsehood (batil) on earth is perennial. It is tantamount to a law of the terrestrial existence. It assumes different forms and spares no segment of human life. At the forefront of such segments stand political leadership and authority, economy and trade, religion, creed and morality, social structure, entertainment, art and architecture. Some examples of the conflicts have been given wherein some of the most prominent prophets featured, such as prophets Musa (Moses), Ibrahim (Abraham), Nuh (Noah), Hud (Eber or Heber), Salih (Shelakh), Lut (Lot) and Shu'ayb (Jethro).

The story of each prophet represents an aspect of the persistent and ubiquitous conflict between good and evil, and between the truth and unbelief and their respective protagonists. The stories and their embedded lessons make up a mosaic of profound cultural and civilisational disorders and how they are to be effectively dealt with. They further illustrate the authentic meaning and significance of life, culture and civilisation, in addition to the types and magnitude of the challenges and obstacles that lie ahead of every bona fide human development and society as well as civilisation-building processes. The surah, thus, is a microcosm of the whole spectacle of life with all its ups and downs, and its message a microcosm of the cosmic truth. 
Another lesson to be deduced from the content of the surah is that all conflicts of falsehood and its people with the truth and its own people are vain. In each case, it is the truth and its ardent followers that eventually emerge victorious and prevail, while falsehood and unbelief with their own adherents are brought low and made perish. It is yet another principle of life that falsehood and unbelief cannot permanently vanquish the truth. They may have their day and score some initial victories, but the ultimate triumph will always belong to the truth and its camp. The truth may lose some battles but will win the wars. Hence, there is no book, or any other epistemological or religious source, that promotes positive thinking and attitude, and inspires as well as motivates better than the Qur'an. It reiterates that nonbelievers, polytheists, oppressors, corruptors and all types of villains will not succeed because they pit themselves against Almighty God. Whereas the believers and doers of good, the God-fearing and the righteous will in the end succeed because they have aligned themselves with the natural and primordial order of things and have God on their side. The truth is the standard and rule, falsehood and unbelief anomalies and aberrations. The Qur'an proclaims, "And say: 'The truth has (now) arrived, and falsehood perished; for falsehood is (by its nature) bound to perish"' (Surah al-Isra', 81). Also, "Say: 'The truth has arrived, and falsehood neither creates anything new, nor restores anything (or, falsehood shall vanish and shall not come back)'" (Surah Saba', 49).

Accordingly, Pharaoh vehemently rejected the teachings of Musa. However, in the end, Pharaoh's magicians, who had been brought forth to support the case of Pharaoh and make him triumph over Musa, bowed to the truth, while Pharaoh and his army were drowned (verses 10-68). Nor did Ibrahim's disobedient people gain anything by their resisting the truth he preached (verses 69-103). Nuh's people also perished by their rejection of their prophet's message (verses 105-122). Moreover, both Hud (verses 123-140) and Salih (verses 141-159) warned their respective peoples against their widespread mischief and against reliance on their material strength - including the built environment - for perpetrating and propagating the former. In the end, in both cases, the evil ones were destroyed. Lut (verses 160-175) likewise had to put up with his people's horrendous delinquencies, and Shu'ayb (verses 176-191) with corruption, disobedience and fraudulent dealings. Their teachings were intensely repudiated, but the wrongdoers were eventually annihilated (Ali 1990; al-Sabuni 1981).

There is nothing more fulfilling and looked-forward-to than happy endings, irrespective of the amount of time and efforts needed for their realisation. That is exactly what people live for. A happy ending is the neutraliser and annihilator of all earlier problems, sadness and desolation. Similarly, an unhappy ending is the neutraliser and annihilator of all earlier comforts, delights and pleasures. When a 
happy ending arrives, it is as though there was nothing else before. By the same token, when an unhappy ending comes, it is as though there was nothing else before. Hence, the Prophet (pbuh) advised Muslims to remember frequently "the destroyer of pleasures, i.e., death" and to act and prepare themselves accordingly (Sunan Ibn Majah, hadith no. 4258).

The message thus communicated to the rejecters of Prophet Muhammad (pbuh) and the final revealed message, i.e., the Qur'an, is that, consistent with the established laws of life and history, the truth will again emerge victorious. The rejecters and disobedient ones will not succeed in suppressing it and extinguishing its light. Their end, especially in the Hereafter, will be as distressing and chastening as that of their earlier counterparts. That is so because the Qur'an is the Creator's revealed word and guidance to humankind:

Verily this is a revelation from the Lord (and Sustainer) of the worlds. With it came down the spirit of faith and truth (trustworthy Jibril or Gabriel), upon your heart that you (O Muhammad) may be (one) of the warners. (Surah al-Shu'ara', 192-194)

According to Maududi (1982), the mentality of the disbeliever has been the same throughout the ages. Their arguments and objections, and their excuses and subterfuges for not believing have been similar and ultimately the fates that they met have also been the same. Likewise, the prophets in every age presented the same teachings, their personal character and their reasoning and arguments against their opponents were the same, and they were all similarly blessed with mercy by Almighty God. Both these patterns of behaviour and conduct are found in history, and the disbelievers could themselves see as to which respective patterns they and Prophet Muhammad (pbuh) belonged.

The Qur'an then in most emphatic terms rejects the prospect of it being a form of poetry (verses 224-227). In terms of its contents, the qualities and virtues of its personnel - including the Prophet (pbuh) himself - and the generated impact on individuals and society, in no way can the truth enshrined in the Qur' an be equated with vain poetry. Nor is the Qur'an brought down by devils (verses 210-212). It is a serious divine message with serious eternal consequences. The Qur'an is the main cause of the Prophet's and believers' success. Its opponents' failure, on the other hand, is due to their rejection of the Qur' an and adoption of other inadequate ideological alternatives instead.

The surah also highlights that for the monotheistic truth, which is so repeatedly and obstinately rejected by numerous nations, innumerable signs (ayat) have been 
presented. They have been sent down or created, and every aspect of creation, including human life and history, has been imbued with them. The signs attest to the presence, greatness and benevolence of the Creator and Lord of the universe. They are easily accessible and obtainable. They just need to be sincerely and dispassionately read, understood and acted upon, so that man could fulfil his honourable vicegerency (khilafah) mission on earth. However, man's inherent impulses and weaknesses - which he refuses to tackle and overcome - and his proneness to heedlessness and self-deception often get the better of him. It plunges and sustains him in the abyss of spiritual blindness and illiteracy. Thus, the surah speaks about the signs (ayat) of the Qur'an (verse 2), the signs in the natural world (verse 8), the exceptionally great signs that God, if He wants, can send down from the heaven (verse 4), the signs given to Prophet Musa (verse 15), the signs in the stories of all the seven prophets mentioned above (verses 67, 103, 121, 139, 158, 174 and 190), and the signs in the lives and conducts of the learned scholars of the Children of Israel who had known that the Qur'an is true and so, embraced Islam (verse 197).

Al-Shu'ara', it goes without saying, is the surah of signs (ayat). It contains 14 references to signs: 12 as the singular (ayah) and 2 as the plural (ayat) noun. Its main themes and repetitive references to signs are meant to serve as antidotes for certain people's adamant denial of the obvious and compelling truth.

\section{The Case of Poetry}

As an art, Arabic poetry is the earliest and perhaps most prominent form of Arabic literature. One thing is the present knowledge of Arabic poetry, which dates back approximately to the 6th century, but the other is oral poetry which is believed to predate that by many centuries (Ratna 2015). Poetry was the only medium of literary expression in pre-Islamic Arabia. In point of fact, it was the only form of art. One of the reasons for that was the remarkable Semitic respect for the word and its inherent potentials and beauties (Peterson 2017). In addition, the cultural and civilisational identities of the Semites throughout history, whereby they appeared to be more cultured than civilised, played also a role. Even during some ancient biblical times, the Arabs were known for their poetry and for what the scholars sometimes call "gnomic wisdom". King Solomon's (Prophet Sulayman) wisdom is said to have been so magnificent that it outshined the wisdom of all the people of the East and all the wisdom of Egypt (Peterson 2017). By the "people of the East", it is meant the Arabs. And Job's (Prophet Ayyub) wise friends, it is clear, come from north Arabian groups. Indeed, the Book of Job as a whole has been argued by some commentators to have an Arabian origin (Peterson 2017). It is described as the greatest poem of ancient and modern times. The Book of Job is in the Ketuvim 
("Writings") section of the Hebrew Bible (Tanakh), and the first poetic book in the Old Testament of the Christian Bible (Seow 2013).

The reference of surah al-Shu'ara' to the poets and its entire context are twofold. Firstly, it proves that the Qur'an is not a work of poetry and that Muhammad (pbuh) is not a poet. Secondly, it asserts that poetry and other forms of art are a double-edged sword. In principle, they are neither good nor bad, and they cannot be generalised and declared as either prohibited or permitted. It all depends on a number of internal and external factors which pertain to the worldview and intention of an artist, his overall conduct and the substance, purpose as well as objective of his art.

The polytheistic Arabs (mushrikun) stopped at nothing trying to justify their rejection of the Prophet (pbuh) and his revelation, the Holy Qur'an. Given that the city of Makkah since time immemorial was a largescale religious hub and a centre of pilgrimage, the Makkans had to continuously explain the case of Muhammad (pbuh) to the visitors and pilgrims that flocked to the city. They had to cautiously disapprove and deride his case so that the other people could become convinced and do the same yet before meeting him. His fascinating and enthralling religious preaching had to be thwarted at all cost.

One of the charges levelled against the Prophet (pbuh) was that he was no more than an extraordinarily skilful poet and the Qur'an nothing more than the product of his great poetic skill and artistry. Therefore, the Qur'an hastened to repudiate such baseless allegations. It highlighted that the Prophet (pbuh) was an unlettered man who had never learned how to read and write (Surah al-'Ankabut, 48). Moreover, the Qur'an was officially his greatest and permanent miracle. It explicitly challenged anybody from among the Jinns or humankind, in any place and age, and individually or collectively, to come up with anything that could rival yet the shortest chapters (surahs) of the Qur'an in terms of their beauty, style, content, meaning and implications for thought and life (Surah al-Baqarah, 23-24). The logic goes to the effect that if the Prophet (pbuh) was a poet and the Qur'an poetry, then many great poets from various times and locations would have taken up the challenge and do away with the menace of Muhammad (pbuh) and Islam once and for all. However, nothing ever to that effect came to pass. Everyone felt so overwhelmed and incapacitated by the style and spirit of the Qur'anic message that nobody even dared to try.

In the context of its defence of the Prophet (pbuh) and his heavenly mission, the Qur'an articulates once the words "poetry" (shi'r) and "poets" (shu'ara') and four times the word "poet" (sha 'ir). The kernel of the Qur'an's defence is the following 
verse from surah Ya Sin, verse 69: "And in no way did We teach him (the Prophet) poetry; and in no way does it behove him. Decidedly (this revelation) it is nothing (else) except a Remembrance and an evident Qur'an".

The message of surah al-Shu'ara' concerning the rejection of the charge that the Prophet (pbuh) is a poet and the Qur'an poetry is as follows. The (dishonest and wrong) poets are followed only by the erring ones (ghawun) (verse 224). Such is the case because the poets speak indiscriminately about basically every subject without seriously considering if they are right or wrong. They roam confusedly and aimlessly "through all the valleys of words and thoughts" (Surah al-Shu'ara', 225). They often talk about sensual pleasures. They tend to excessively jest, parody, glorify and criticise. If situations demand and their personal objectives warrant, they and their poetry also arouse the feelings of hatred, enmity and vengeance against others.

The poets are often loose cannons, submitting themselves to no spiritual and moral restrictions or authority. Their absolutely free and intensely imaginative and fantasising minds and souls are the only sources of legitimacy to them. Every knowledge or initiative ought to be turned to that frame of reference for its authentication and endorsement. In their world, there is no place for the higher standards and nobler ends of life. Hence, the surah, apart from alluding to the fact that the poets - and many other artists - are lost and blind, accentuates the inconsistency between what they say and do (Surah al-Shu'ara', 226), which is a serious deficiency most commonly found among hypocrites. The verse thus also indicates the inconsistency between the ideas, creativity and dreams of the poets and the implications of living a real life (Maududi 1982; al-Qurtubi 1967).

If this is the case with the (immoral) poets, the same holds true for their sympathisers and followers. They complement and sustain each other. They make up an exclusive sphere of concepts, traditions and mores under the guise of art (poetry). Indeed, he who is in demand and is followed dictates the religious convictions and ethical behavioural paradigms of those who pursue and follow him. Correct is the Latin phrase: "Cuius regio, eius religio", which is translated as "whose realm, his religion". Ibn Khaldun also rightly observed that the common people follow the religion (creed) of their rulers, or leaders, in every sense of every word in the idiom (Wan Razali and Awang 2016).

The passionate followers of the (immoral) poets are called "ghawun", which broadly means "the erring ones". The term, in fact, implies any type or category of people who are misguided and live in error. In that case, the poets are guilty of a dual spiritual misdemeanour: being misguided themselves and misguiding the 
others. In order to underscore the seriousness and profundity of the matter, the surah uses the same term twice more, apart from the case of the poets in verse 224; that is in verses 91 and 94 . Both instances are mentioned in connection with Hellfire and the conditions of its inhabitants. Verse 91 of surah al-Shu'ara' reads: "And Hell will appear plainly to the erring ones (or those who were straying in Evil or were lost in grievous error) (ghawin)"; and verse 94 reads: "Then they will be thrown headlong into the Hellfire, they and those who were (lost) in (grievous) error (ghawun)". It is also interesting to note that the same word with its derivatives is employed elsewhere in the Qur'an predominantly in the context of Satan and his unceasing scheming that aims at deceiving man and causing his fall. Therefore, whoever does the same thing and adopts the similar deceptive strategies follows in the footsteps of Satan.

On the other hand, those who follow the Prophet (pbuh) constitute together with him a community that possesses a highly cultured, refined and kind behavioural paradigm. Its existential purpose and mission are rooted in universal righteousness, God-consciousness, a sense of commitment for higher ontological ideals and ends, and a high regard for the rights of others. Topping the list of its priorities are fairness, justice and comprehensive excellence. To its people, life is an extremely serious business with correspondingly serious consequences. No human pursuit is to deviate, even in the slightest, from this outlook and the action-plans that emanate therefrom.

It is in relation to this that the surah asserts that the Qur'an is God's speech and His revelation (verse 192). By describing Himself in the same verse as "the Lord of the worlds" as the source of the revealed Qur'an, God wants to suggest that His revelation is total, encompassing the whole truth, and universal, aiming at everyone and every circumstance and everywhere till the end of time. God sent the Qur'an down through the archangel Jibril (Gabriel) who is His trustworthy messenger from the realm of angels (verse 193). Thus, the Qur'an came from Almighty God, the Creator and Lord of the universe, through the trustworthy archangel Jibril (Amin) and to the Prophet (pbuh), who as well was nicknamed Amin (the trustworthy). The project started in Makkah, which was dubbed the city of protection and security (balad amin) (Surah al-Tin, 3). The concepts of "trustworthiness" (amanah) and "protection" (amn) are interrelated, overlapping each other in many respects. It is almost as though there can be no one without the other. The root of both words is the same.

All that by no means is a coincidence. The whole case of the Prophet (pbuh) rested on the absolute and divine authority and on the premises of total trustworthiness, authenticity, integrity and infallibility. It aimed to create generations of people 
who will epitomise in their deeds, words and attitudes trustworthiness, virtue and honesty. Being thus at peace with themselves, they could become a source of peace, motivation and guidance to others.

The same is true with regard to every other prophet. Trustworthiness (amanah) was the paramount quality of each and every one of them. The reliability and integrity of every stage and aspect of revelation had to be ensured and substantiated. Five of the seven prophets whose stories are featured in surah al-Shu'ara' are reported in the same surah to have conveyed to their respective communities the following message: "Will you not fear (be conscious of) Allah? I am a trustworthy messenger (rasul amin) to you. So fear (be conscious of) Allah, keep your duty to Him, and obey me". The five prophets are Nuh (verses 106-108), Hud (verses 124-126), Salih (verses 142-144), Lut (verses 161-163) and Shu'ayb (verses 177-179).

Owing to this, the surah categorically states that "it is not devils who have brought it (the Qur'an) down. Neither would it suit them, nor can they (produce it). Verily, they have been removed far from hearing it" (Surah al-Shu'ara', 210-212). However, putting forward that every ideological alternative that tends to rival the Qur'an and its straight path is partly or completely Satan's business, the surah conveys: "Shall I inform you (O people!) on whom it is that devils (the evil ones) descend? They descend on every lying wicked person. (Into whose ears) they pour hearsay vanities and most of them are liars" (Surah al-Shu'ara', 221-223).

That the case of the poets follows immediately after the latter set of verses clearly shows how tricky, double-sided and devious poetry - and other art forms - could be. As a means, rather than end, its legitimacy, or otherwise, depends on how and for what purposes it is used. Just as it can procure much goodness, it likewise can generate much harm. That the allusion to the negative sides of poetry precedes the positive ones may suggest that the former outweighs the latter in its potency, effects and scope. It may also suggest that the former is more needed by falsehood and disbelief to establish themselves and thrive, than the latter by the truth. The truth is objective and self-governing. A great deal of the creativity and resourcefulness of the wicked and dishonest poets and other artists, which is proportionately wicked and dishonest, is nothing but Satan's whispers. As equal partners, they move together and cooperate towards the same ungodly ends.

Still, there is much room for appropriate poetry and art in Islam and its civilisation, provided the divine criteria are duly observed. Those criteria are clearly spelled out in verse 227 of al-Shu'ara' where God speaks about the exceptions to the previously stated poetry trends and its proponents: "Save those (poets) who believe and do good works, and remember Allah much, and vindicate themselves 
after they have been wronged. Those who do wrong will come to know by what a (great) reverse they will be overturned!"

This verse is the last verse in surah al-Shu'ara'. Its role is akin to the final and parting emphasis on the most important thing that permeates virtually every section of the surah, that is, the identity of the truth and its salient features. The truth must set up a backdrop for every human activity. Its essence must be its beginning, means and end. Abdullah Yusuf Ali (1990) further elaborates:

Poetry and the fine arts which are to be commended are those which emanate from minds steeped in faith, which try to carry out in life the fine sentiments they express in their artistic work, aim at the glory of Allah rather than at self-glorification or the fulsome praise of men with feet of clay, and do not (as in jihad) attack anything except aggressive evil. In this sense a perfect artist should be a perfect man. Perfection may not be attainable in this life, but it should be the aim of every man, and especially of one who wishes to become a supreme artist, not only in technique but in spirit and essentials.

Nobody disputes the innate permissibility of poetry. It is like any other form of speech: what is good is good, and what is evil is evil. In view of that, the Prophet (pbuh) was never against proper and beneficial poetry. Yet, he himself sometimes recited certain poetry verses, or he asked someone to recite to him. However, his interest in poetry was lukewarm and he never memorised whole poems verbatim, nor did he intend to. He is reported to have said that in some poetry, truly, there is wisdom. He also remarked about a non-Muslim poet that he is almost a Muslim in his poetry (Ibn Kathir 2000; al-Razi 1990; Misra 2010).

Likewise, some of the Prophet's (pbuh) companions were fond of the subject. Some mastered it and were renowned poets. However, they used their talent only for defending and promoting the truth and its people. No inappropriate aims found their way into their poetry interests and hobbies. A companion, Hassan b. Thabit, was one of the most outstanding poets of the Prophet (pbuh). He used to recite poetry inside the Mosque of the Prophet (pbuh) and in the presence of the Prophet (pbuh) who once said: "O Hassan! Reply on behalf of Allah's Messenger (to the attacks of the polytheists by means of poetry). O Allah! Support him with the Holy Spirit (angel Jibril or Gabriel)" (Sahih al-Bukhari, hadith no. 444).

Not only that, the Prophet (pbuh) even set up a pulpit (minbar) for Hassan b. Thabit in his mosque to defend him and his mission, and to lampoon or compose satirical poetry defaming the infidels and their agendas against the Prophet (pbuh) and his Islamic cause (al-Samahudi 1997). According to a report, once a man started 
abusing Hassan b. Thabit in front of 'A'ishah, the wife of the Prophet (pbuh), whereupon she said: "Do not abuse him, for he used to defend the Prophet (pbuh) (with his poetry)" (Sahih al-Bukhari, hadith no. 3531).

\section{The Case of Architecture}

Architecture is becoming more important than ever in the spheres of cultural and civilisational developments. Yet, it is becoming vital for the survival of humans. According to some estimations, around 90 percent of contemporary human existence unfolds within the domains of various forms of built environments. Especially because more and more people migrate from rural to urban areas, living as a result in poorly planned and built city's expanded areas and slums - in particular in developing countries - it is also a well-known fact that "the onset of illness and death is more rapid and often more prevalent as a result of inadequate shelter than of inadequate food supply" (Caicco 2005). Based on a recent research, the construction sector contributes to 23 percent of air pollution, 50 percent of the climatic change, 40 percent of drinking water pollution, and 50 percent of landfill wastes. It also accounts for 40 percent of worldwide energy usage (McNally 2017).

The world of the built environment with all of its professions, diverse spans and hierarchical decision making and implementational processes is very sensitive and challenging. It is an all-pervading phenomenon. Construction activities, including design, planning, construction and maintenance, contributes significantly to human societies economically and socially. Its relationship to the public's health is also essential. Inasmuch as it involves mindboggling amounts of funds, it is susceptible to some of the most unethical practices. Its significance and overall impact on development are becoming so colossal that, soon, societies' civilisational agendas will be able to succeed predominantly on account of the appropriate character and function of the built environment. Those agendas' failure will likewise be largely attributable to the failure of the latter. The construction sector and national economies are increasingly intertwined in reciprocal and causal relationships.

It is thus astonishing that comprehensive ethical discourses are comparatively non-existent within the contemporary built environment professions and practices. Whereas most of their scientific and professional counterparts fare much better. However, the situation was not always as serious as now. The stage for the predicament of global proportions was set when people started abandoning their traditional ways of thinking and doing things in favour of the modern materialistic and nihilistic norms, values and practices, as part of the evolution of the modern philosophical and scientific worldviews and value systems which, in turn, led to the creation of the modern and much different cultural and civilisational penchants. 
According to Caicco (2005), whenever 18th-century Enlightenment principles were uncritically adopted or imposed by force around the world, architects and designers - often in tandem with their clients and communities of users - rapidly abandoned their traditional discourse and practice of ethics, bowing to the demands of utilitarian market forces.

Since surah al-Shu'ara' is about the meaning and spirit of prophethood and spiritual light and their perennial conflict with the forces of falsehood and darkness, it dwells extensively on various life patterns that the latter may adopt regardless of the vicissitudes of time and space. Those patterns are correlated with the critical life sectors of political leadership and authority, economy and commerce, faith and morality, social structure, entertainment, art and architecture. The story of every prophet and his community featured in the surah corresponds to one or more of such life sectors.

As far as the subject of architecture is concerned, it is brought up in connection with the stories of prophets Hud, Salih and Musa. The stories highlight different dimensions of architecture. When put together, they exhibit what could be described as the foundation and nucleus of the Islamic worldview for architecture and Islamic architectural ethics. This shows that Islam regards the built environment as indispensable to life. It finds it critical to man's cultural awareness and civilisational progression. In terms of importance and value, it is on a par with any other foremost segment of civilisation.

Firstly, as part of the story about prophet Hud and his rebellious people, 'Ad, the surah reveals that Hud reproached his people for their constructing of landmarks, monuments and high palaces (ayah) on every high place for vain delight and just to amuse themselves (verse 128). They did not need those structures. They signified a means for showing off and demonstrating their might and worldly riches which God had bestowed on them in abundance. Similarly, they wanted everyone from their enemies, competitors and neighbours to hold them and their material strength and development in awe. Instead of being grateful for the blessings, their transgression and misbehaviour were aggravated thereby. That seems to have been part of their total behavioural mould as tyrants, for in verse 130 of al-Shu'ara', a hint is given to their typical behaviour with their adversaries: "And will you (always), whenever you lay hand (on others), lay hand (on them) cruelly, without any restraint?"

Hud also admonished his people for building fine and strong buildings, castles or fortresses (masani') in the hope of becoming immortal and living in them forever (verse 129). This shows that 'Ad's mischief knew no bounds. It originated in a faulty worldview and clearly manifested itself in architecture as a framework 
and physical locus of all human consequential pursuits. Their main problem concerned as much fundamental ideas, beliefs and standards as the absence or non-application - of appropriate architectural moral principles and codes of conduct. Their built environment was their raison d'etre and it epitomised their existential ethos. Their non-belief was hard-core. As a finished product, it crept into and dominated all sides and features of their civilisational consciousness and presence. Architecture is singled out in the story owing to its extraordinary deeprooted import and position.

Hud knew the crux of the problem. Thus, he repeats to his people that they should be God-conscious and fear Him (verses 124, 126, 131-132), in that God-consciousness (taqwa) is the cause of all goodness, while the lack of it and espousing other things and ideas as forged alternatives, denote the cause of all wrongdoing. He insists that as a trustworthy messenger of God, they should obey and follow him (verse 126). Only that way will their initiatives and creations - including such as within the realm of architecture - attain legitimacy and acceptability. Only that way, furthermore, will the identities and functions of their architectural creations be compatible with other more consequential life dimensions and goals for which they were supposed to exist and which they were supposed to serve. Architecture, both as a theory and standard of living, is so intense and overwhelming that a person lacking the right orientation and goal may easily get lost inside its infinite expanse and depth. He may yet be consumed by it. Underscoring this point - parenthetically - Koca Mimar Sinan, the chief architect of the Ottoman golden age, called architecture an "estimable calling" and said that whoever wanted to practice it correctly must be, first of all, righteous and pious (Freely and Burelli 1996).

Hud moreover pleaded with his people to keep their duty to their Creator and Lord. He asks them not to be arrogant, heedless and to be grateful for all the good things with which God had aided them and which they were fully aware of. Their architectural talent and creativity were also a divine gift and grace. They needed to reciprocate by subjecting the gifts and flairs only to the aims consistent with the metaphysical ends. If not, Hud feared for his people the torment of a great day when they will lose everything and perish (verses 131-135), when their material progress might be used against them and their fine and monumental architecture as their necropolis. It will be then that they will understand where the truth and where falsehood laid, and who was who in the entire scheme of things and events. They will understand the real meanings of prosperity, success and happiness as well. Such dawning realisations will be coupled with the senses of guilt and bitter regret, but at that point, it will be too little too late. By then, they will have exhausted all the afforded options, munificence and sympathy. 
The gravity of the architectural reality of prophet Hud's people can additionally be established by the following. When Hud refers to his people's erected landmarks, monuments and high palaces in verse 128, he calls them signs (ayah). To make a reference to that particular point in surah al-Shu'ara', whose gist and central idea pertain to the affirmation and exhibition of signs (ayat) throughout the multidimensionality of creation and human behaviour, takes on extra significance. It shows that 'Ad's conduct was a grim syndrome of epidemic proportions. It morphed into a complete way of life that was firmly implanted in a philosophy and coherent set of values. As such, it not only opposed, but also challenged epistemologically as well as conceptually the articles of faith and value system preached by Prophet Hud. They saw in Hud and his mission nothing superior to them and what they concocted and blindly followed. Hence, they replied to him: "It is the same to us whether you admonish us or be not among (our) admonishers. This is no other than a customary device (fable or myth) of the ancients. And we are not going to be punished" (Surah al-Shu'ara', 136-138).

Besides, another perspective can be offered. According to it, firstly the verb "tabnun", which means "you are building or erecting", is used in the couple of the verses of the story which explicitly deals with "Ad's architecture. The verb connotes a means for achieving something extra. That something is mentioned at the end of the same verse, verse 128, namely the verb "ta'bathun", which means "for vain delight and to amuse yourselves". However, the latter is not an end par excellence. Rather, it is a yet more complex and intense means which is used at yet a higher level of meaning and operation. That level is indicated in the subsequent verse, verse 129. In it, the first two words suggest the transformation of the means and channels into an all-out strategy and outlook, namely "tattakhidhuna Masani", which means "you get for yourselves strong buildings, castles or fortresses". The first word of the two is "you get, embrace or champion for yourselves", rather than "you build for yourselves". While the latter signifies a sheer method and course of action, the latter denotes a fully developed culture, ethos and identity.

That implies that Hud's people's building philosophy, style and culture have become deeply embedded in their minds and souls. There was no turning back. They were identifiable with their built environment. It became them, and they became it. And the last two words in the pair of the verses on 'Ad's architecture are "la'allakum takhludun", which mean "in the hope of becoming immortal and living in them forever". With this, the whole process of 'Ad's architectural deviation was completed. It started with building for wrong objectives and by resorting to unethical norms. It eventually evolved into a sophisticated life model that became so extreme that it contradicted not merely the spiritual and ethical systems brought by prophet Hud, but also the fundamental laws of nature. 
Thereafter, 'Ad's architecture became entangled in a vicious circle. Its outcomes were iniquitous because they fed on the commensurately iniquitous principles and actions associated with the builders, patrons and users, while the norms, attitudes and codes associated with the integrity of the stakeholders' principles and character were iniquitous because the outcomes, due to their palpable deficiencies and longterm uncertainties, lacked bona fide and sustainable legitimacy, inspiration and authority.

Second is the case of Prophet Salih and his people, Thamud. According to surah al-Shu'ara', while preaching to his disobedient people, Salih said to them that they were carving out or hewing dwellings out of the rocky mountains with great skill (verse 149). He did so in order to remind his people of all the great blessings that God had granted them. They should have been more grateful and humble, using the heavenly blessings and gifts aright. They should have employed them as a means for worshipping and serving God, rather than for disobeying Him and mistreating people (Ibn Kathir 2000; al-Razi 1990; al-Tabari 2013). Furthermore, they should have used them for creating such a built environment as could exemplify the truth and aid its application.

Muhammad Asad (1980) explains that the rock-houses or abodes mentioned in verse 149 correspond to:

The elaborate rock-dwellings or tombs - to be seen to this day - which the Thamud carved out of the cliffs west of Hijr, in northern Hijaz, and embellished with sculptures of animals as well as many inscriptions attesting to the comparatively high degree of their civilization and power. In popular Arabian parlance, these rock-dwellings are nowadays called Mada' in Salih (The Towns of Salih).

Thamud were told to fear God, be God-conscious, keep their duty to Him and obey their prophet (verse 150). They were told to wake up and open their eyes and minds and not to lose themselves in the worship of insincere power, wealth and the prevailing fashions of erroneous thought. Otherwise, their might and worldly prosperity - including the remarkable architectural achievements - will in the end count for naught (al-Qurtubi 1967; Ibn Kathir 2000; al-Tabari 2013).

As stated by Abdullah Yusuf Ali (1990), Thamud were told: "All your skill is very well; but cultivate virtue and do not follow the ways of those who put forward extravagant claims for men's powers and material resources, or who lead lives of extravagance in luxury and self-indulgence". 
Like any other act of transitory immoral extravagance, Thamud's architectural greatness was an instrument of self-deception. It maintained and worked for an intellectual and spiritual mirage. However, it was set to expire soon, just like their very selves and their false hopes and dreams. Hence, they were explicitly warned not to subscribe to, nor practice, extravagance and mischief. They were not to spread corruption in the land (verses 151-152). Rather, tapping into their divine gifts and talents, they were asked to reform their ways and set things right. In other words, they, together with their civilisational output, were asked to become assets on earth, instead of liabilities.

Thus awaken, Thamud were meant to be enabled to see that they and their especially architectural accomplishments depended entirely on God's grace and His bounties spread throughout His creation. They were reminded of the boons of security, gardens, springs, green crops, fields and date-palms with soft spadix, which they enjoyed (verses 146-148). They overlooked the verity that they needed nature and the benefit of its total subjection to man's use by God in order to perform. They needed to cooperate with nature and harmoniously borrow and process its raw materials so that their architectural feats could be completed. They also took for granted their intellectual and creative abilities. Accordingly, if they were given, they also needed to give. If they were taken care of, they also needed to take care of. They were not bequeathed with extraordinary gifts because they utterly deserved them, or because God preferred them over other tribes and communities, but because God wanted to test them thereby. God as well intended to make them the instruments of devoutness and reform, but they refused to comply and meet the terms.

Thamud were thus given a blueprint for the true sustainable development. They were advised how to make sure that their amazing built environment and civilisation as a whole will become physically and spiritually compatible with the forces and ontological laws of the natural environment. They were also taught how to make sure that the legacy of their built environment could live on and contribute to the well-being of the future generations and their own civilisational quests. However, if they turned against their prophet and, by extension, their Creator and their intrinsic natural disposition, the edifice of their civilisation will be in danger of collapsing and getting wiped out (verses 146-148). Everything they had will be used against them. The act of divine punishment, when happens, will be tantamount to an act of self-destruction preceded by various acts of self-betrayal. Their ruins will then become a sign of how unsustainable their civilisation - including architecture was. It will become a sign of how things are not to be done. 
At long last, since Thamud did not heed their prophet's counsels and admonitions, what they had been warned about came to pass. The Qur'an elaborates on the fall of Thamud as follows in surah Hud, verses 66-68:

So when Our decree came to pass, We delivered Salih and those who believed with him by mercy from Us, and (We saved them) from the disgrace of that day; surely your Lord is the Strong, the Mighty. And the rumbling overtook those who were unjust, so they became motionless bodies in their homes, as though they had never dwelt in them; now surely did Thamud disbelieve in their Lord; now surely, away with Thamud.

In their immoral attitudes and practices, Thamud did not differ much from their predecessors, the 'Ad people. They followed a similar mode of mischief-making and waywardness. Architecture was an effective means of communication and a canvas for expressing convictions and articulating preferences. Thamud were also cousins to 'Ad, perhaps a younger branch of the same race. While 'Ad resided in the southern part of Arabia, Thamud did in the northern part. Consequently, prophet Salih said to Thamud, as disclosed in surah al-A 'raf, verse 74: "Remember how you were made the heirs (inheritors) of 'Ad and settled in the land, capable of building mansions in the valleys and carving out homes in the mountains. Therefore, remember the favours of Allah and do not spread mischief in the land".

It follows that Thamud were so blind and engrossed in worship of the false glitter of the power and wealth of this world that they did not learn anything from the fate of their ancestors. Rather than learning, they became yet another historical lesson to be learnt from. Rather than becoming a symbol of success, they became a symbol of failure. Some vestiges of the houses of the Thamud people were still in existence during the time of Prophet Muhammad (pbuh). He wanted his companions - and everyone else after them - to learn from what had befallen those people. Once when he and his companions were passing by Hijr - the homeland of Thamud - the Prophet (pbuh) told his companions: "Do not enter the dwellings of these tormented people except in the state of weeping. If you do not weep, do not enter, lest what had befallen them should befall you too" (Sahih al-Bukhari, hadith no. 415).

Finally, Maududi (1982) commented that "just as the most prominent feature of the 'Ad civilisation was that they built large edifices with high pillars, so the most prominent feature of the Thamud civilisation for which they were known among the ancient peoples was that they carved out dwellings in the hills. That is why in surah al-Fajr, the "Ad have been referred to as "(people) of the pillars", and the Thamud as "those who hewed rocks in the valley". These people also built castles 
on the plains, the purpose and object of which was nothing but display of wealth and power and architectural skill as there was no real necessity for them. These are, in fact, the ways of the perverted people: the poor among them do not have proper shelters, and the wealthy members not only have sufficient fine dwellings but over and above those they raise monuments for ostentation and display.

Third is the case of Prophet Musa and Pharaoh, which is the first in surah alShu' ara'. Towards the end of the story where it is alluded to the end of Pharaoh and his party, God says: "So, We expelled them from gardens and springs, treasures and every kind of honourable place (sumptuous dwellings). Thus (were those things taken from them) and We caused the Children of Israel to inherit them" (Surah al-Shu'ara', 57-59).

The message of these verses resonates throughout the stories of the 'Ad and Thamud peoples as well. The message brings home that when a man pits himself against God and the established spiritual and moral laws, he is bound to lose. The same applies to groups, and entire nations, and their endeavours. This is so because Almighty God as the Creator and Master of all creation is ceaselessly glorified and worshipped by every animate and inanimate, spiritual and physical, being in the heavens and on the earth, except certain factions of defiant and wayward humans and Jinns. This is a truth so compellingly expounded by the Qur'an and the Prophet's Sunnah. Hence, submitting to Almighty God is a rule, rejecting and disobeying Him an exception. Worshipping Him is an ontological standard, while denying Him is an invented anomaly.

With that said, man was created but in full agreement with the existing spiritual mould of life. He was decreed and guided to fit into it and was given all the necessary means and facilities to do so. His life mission is all about recognising God, believing in Him and fulfilling the authority of His divine will and revealed word.

Man alone is an inept, vulnerable and indigent creature, notwithstanding his remarkable intellectual prowess which, when all's said and done, is nothing but a gift from the Creator. The gift is intended to be used correctly and for the right ends; not misused or abused. It is intriguing that man is fully aware of his weaknesses. He therefore tries to hide, or mitigate, them, focusing on and making the most of his limited strengths instead.

Nonetheless, man's true character in the end always comes to the fore, for it is impossible to hide the obvious and compulsive. As a result, his longing for eternity and perfection incessantly rage and is insatiable. It became a hallmark of each and 
every human civilisational phase. Some of the greatest cultural and civilisational undertakings of man throughout history reflect such an arduous quest of his. They reflect his yearning for his other and supernatural self to be elevated to another and supernatural sphere. His accomplishments cry for eternity and impeccability, every so often morphing into acts of desperation.

On account of its inherent position and value, architecture proved one of the most fertile grounds for the purpose. Superhuman greatness and immortality are often sought through it. Ironically, however, via architecture, human fragility, flaws and vulnerability are not only exposed, but as well exacerbated. That is the case because under normal circumstances, architecture survives its architects, engineers, patrons and generations of users. It highlights their transience and evidences their mortality and failure in pursuing false dreams and hopes. That becomes even more manifest and severer in impact when juxtaposed with enduring architecture which, too, is transient, but outlives its stakeholders by eons and generations. It seems as though it calls cynically: Where are my creators and cohorts of owners and users? Needless to say, that even in the realm of impermanence and transience, let alone infinity and constancy, man fares poorly and cannot survive on his own.

Man's power, lifecycle and influence on the realities of life come into view as marginal - virtually non-existent - if meticulously studied and compared with myriads of physical and metaphysical actualities. Architectural remnants offer that learning opportunity better than a great many other segments of civilisation. Instead of proving man's superhuman importance and greatness - as originally planned - architecture, in fact, proves his inconsequentiality and smallness.

Thus, in the surah, in the context of the conflict between Prophet Musa and Pharaoh, God underlines the nature and scope of Pharaoh's and his party's failure and demise. Such manifested itself in the fact that they were all defeated by God's direct intervention. They all vanished, leaving everything they owned behind. They neither carried anything along, nor could their pomp and riches avail them of any respite or sympathy. What accompanied them to the Hereafter were only their (mis)deeds.

Moreover, what they accumulated and delighted in - including sumptuous private and public buildings - passed into the hands of others, in this case their adversaries. The episode became a sign for posterity, attesting to Pharaoh's and his party's spiritual and moral bankruptcy and ultimate ruin. It follows that if a community with its generated legacy really wants to live on and write genuinely successful chapters in history, what Pharaoh - as well as the "Ad and Thamud peoples - did, certainly is not the way to follow. In the same vein, the way they all conceived, 
fashioned and used their architecture - so as to personify, facilitate and advertise their materialistic and hedonistic lifestyles - is not the way to go about either.

\section{Creating and Reading Art and Architecture as Signs}

Surah al-Shu'ara' is a surah of signs (ayat), so to speak. It refers 14 times to signs: 12 as the singular (ayah) and 2 as the plural (ayat) noun. It affirms that the whole of creation, big and small, great and insignificant, is replete with signs (verses 7-8). The signs testify to the existence, greatness, wisdom and compassion of the Creator and Master of the universe. They are easily accessible and attainable, provided unprejudiced, keen and sensible minds and souls observed and studied them. The whole of creation, it follows, is an open book ready to be explored and read.

The same applies to the history of humankind and people's imprints on the evolution of civilisation. The case of every nation represents a unique lesson (sign or ayah) that complements the cases of other nations, exemplifying thereby the totality of human cultural and civilisational consciousness and yield. A significant part of such a historical mosaic is presented in the surah, featuring seven prophets and the spiritual as well as civilisational conditions of their communities. Hence, at the end of each story, the following phrase is repeated: "Verily, in this is indeed a sign (ayah), yet most of them are not believers. And verily, your Lord, He is indeed the Almighty, the most Merciful' (Surah al-Shu'ara', 67-68, 103-104, 121-122, 139-140, 158-159, 174-175, 190-191).

Surah al-Shu'ara' signifies a microcosm of the civilisational development of humankind. It focuses on its soul and direction, and its relationship with the truth: its origin and main protagonists. All in all, the history of man and human society is the history of the conflict between the truth and falsehood, between good and bad, and between the darkness and light, and how the general human progress was unfolding in the midst of such encounters and confrontations.

On top of all this, the prophets were given revealed signs as well, regularly in the form of Holy Scriptures, to be conveyed to people. The last of such scriptures and books is the Holy Qur'an revealed to the last prophet, Muhammad (pbuh). It is most comprehensive and impactful as regards the subject of signs. Due to that, the surah commences with the words: "These are the verses (signs or ayat) of the manifest book (the Qur'an)" (Surah al-Shu'ara', 2). The verse thus sets the tone for the entire surah. 
However, customarily, the people were so engrossed in ignorance and sin that they bartered the simplicity, clarity and rationality of the signs of the book of revelation (Qur'an) and the sings of the "book" of creation for the vagueness, insecurity and irrationality of falsehood and its own "signs". Similarly, the hard-hearted Makkans learned nothing from any set of available signs. They simply did not want to. Neither did they get anything from the eventual fates of the earlier defiant nations. They did not understand that they were indirectly asked as to which path - and destiny - they wanted to follow: the path of the deniers and villains, or the path of the prophets and their rightly-guided followers.

As a result, Prophet Muhammad (pbuh) developed a serious sense of grief, anguish and anxiety over the Makkan disbelievers' moral degradation and opposition to his message of reform. Sometimes it seemed as if his grief and mental suffering for their sake would cause his death. So, God revealed to him: "You will perhaps fret yourself to death with grief because they do not believe. If We wanted, We could send down upon them a sign from the heaven before which they would bend their necks in submission and humility" (Surah al-Shu'ara', 3-4).

If it had been God's will and plan to force people's will, He could quite easily have forced the Makkans. But His will and plan work differently. His revelation is meant to train man's own will so that it conforms to God's beneficent purpose (Ali 1990). The spiritual value of man's faith depends on its being an outcome of free choice and not of compulsion. There was a plethora of signs available for the people, on the basis of which they could easily find, comprehend and embrace the truth and its ways. The visible or audible appearance of a "message from the skies" was unnecessary. Furthermore, by its very obviousness, it would nullify the element of free choice, and therefore, deprive man's faith in that message of all its moral significance (Asad 1980; al-Razi 1990). Belief under compulsion is not acceptable to God. He wants that people should use their common-sense and recognise the truth through the verses (signs) of the Qur'an and the signs which are scattered all over the universe and are found even in their own selves (Maududi 1982).

Consequently, all forms of human productivity and creative engagement in the arenas of culture and civilisation are likewise to serve an ontological purpose. They are to be transformed into human-made signs and be an extension of the created and revealed signs (ayat) of God. They are to be seamlessly integrated into the latter. As such, they are to function as an instrument of enhancing and promoting the truth. They, in equal measure, are to endorse, communicate and further enrich it. Human life is to morph into a dynamic and refined interplay between the divine and human-generated signs, and the heavenly splendour and majesty, and humanconceived and effected beauty. 
If the immoral poets created poetry and the disobedient 'Ad and Thamud peoples, as well as Pharaoh and his hosts, created architecture in such a way that they epitomised, promoted and functioned as signs of non-belief and falsehood, rendering righteously functional art and architecture as effective signs of goodness and virtue can also be achieved. Such should be endorsed as integral to the function and identity of Islamic art and architecture. Creating and reading art and architecture as signs can be put forth as a validation of an intellectual and even spiritual advancement. That will certainly lead to the betterment of the state of Islamic art and architecture and will enhance people's genuine affiliation with and participation in them.

In addition to the revealed book of sings (ayat), which is the Holy Qur'an, and the created "book" of signs, which is the universe, the authentic forms of Islamic art and architecture should function as a third book of signs. From the first book, the third book should derive its meaning, significance and purpose, and from the second its ethos, identity and overall utility. This additionally means that inappropriate artistic and architectural styles conflict not only with the spiritual canons and values, but also the laws of nature and human primordial self. They are at odds not only with heavens, but also the earth.

The complete and profound reading of the book of revelation and the book of creation, and meticulously integrating them, is entailed in the first revealed word and injunction to Prophet Muhammad (pbuh): "Read! In the name of your Lord who creates" (Surah al- 'Alaq, 1). Or else, how could the unlettered person, that is, the Prophet (pbuh), who had never learnt how to read and write, be instructed to read?

Islamic art and architecture must function only according to the behavioural patterns prescribed by the Qur'an and Sunnah. The spirit of their function should be consistent with the spirit of the function and comportment of their owners and users. For example, the principles of environmental protection, comprehensive excellence, hygiene, safety, health, fairness, balance, moderation, beauty, appropriate purposefulness and functionality, etc., are to be found implemented and promoted both by the people and their art and architecture at their respective planes. Such a state of affairs, in turn, will be placed within the context of a much larger milieu, which is the whole of creation, but which also operates on the strength of the same principles. As God's vicegerent on earth, all of man's earthly undertakings are supposed to aim at realising that of-the-highest-order harmony and equilibrium. Art and architecture, too, are to be employed in the service of the latter. 
Driven by the same impetus, Muslim artists and architects developed in their respective fields a culture of drawing the attention from the upshots of human endeavours to a higher order of expression and meaning. They thus intend to humbly demonstrate that they harbour no might, defiance or self-assertion when it comes to the appropriating of and acting in the space that does not belong to them; it belongs to God the Almighty, the Creator and rightful Owner of everything, including man, his total being and his talents. They, furthermore, tend to depict themselves as servants rather than masters, as trustees rather than owners, and as modest mortals rather than pretentious creators.

For example, in Islamic architecture, mass - time and again - is literally made invisible. This is achieved by covering it with stucco, tile, wood and other materials that transfigure the mass into something radically and totally new and different (Al-Faruqi 1981). Buildings simply appear as though enveloped within dissimilar pleasing, dynamic and contemplation-provoking webs of coloured decoration. They invite attention and ask not merely to be enjoyed, but also "read" and "understood". They divert the focus from the physical to the spiritual world, and from the creation to the Creator. Sometimes when no rich decoration with plentiful motifs and themes is used on a building's surfaces, due to the lack of, say, materials, expertise, resources, or even interest, other practical alternatives are conceived instead, so as to satisfy the same Islamic aesthetic taste. Some of such alternatives are wide-ranging brick patterning, when brick is a major building material; the clever use of marble and stone in bands of contrasting colours, when stone is a major building material (Hillenbrand 1999); laying emphasis on ingenious symmetry in design as well as in organisation of inner spaces and architectural motifs, and so on. While discussing the subject of decoration in Islamic architecture, its techniques, language and materials, Ibn Khaldun (1967) concluded: "Thus, the walls come to look like colourful flower beds".

\section{Conclusion}

The salient theme of surah al-Shu'ara' is the conflict between the truth and falsehood and their protagonists on earth. The surah shows that the conflict is constant. It amounts to a law of life, taking up different forms and sparing no sector of human existence. The sectors that are most affected are: political leadership and authority, economy and trade, religion, creed and morality, social structure, entertainment, art and architecture. Many examples of the conflict and its prevalent dispositions have been presented in the surah. They feature some of the most prominent prophets: Musa, Ibrahim, Nuh, Hud, Salih, Lut and Shu'ayb. The case of Prophet Muhammad (pbuh) and the nature of the challenges to his mission are also featured. They are subtly linked with the other historical cases. 
The main purport of the surah lies in its stress on the unchanging character of man's weakness and proneness to self-deception. That explains why the great majority of people, at all times and in all communities, so readily reject the truth - whether it be the truth of God's messages or self-evident moral values. In consequence, people lose themselves in a worship of power, wealth and what is commonly described as "glory", as well as in a mindless acceptance of slogans of the prevailing fashions of thought (Asad 1980).

The surah underscores that Prophet Muhammad (pbuh) was not a poet and that the Holy Qur'an is not a form of poetry. The arduous prophetic mission of the Prophet (pbuh) rested on the absolute and divine authority and on the premises of total trustworthiness, authenticity, integrity and infallibility. It aimed to create generations of people who will epitomise in their deeds, words and attitudes trustworthiness, virtue and honesty. This by no means is akin to the purpose and job of poets who operate mainly for the sake of pleasing the people and winning their applause and accolades, and who are followed by the like-minded individuals and groups (the erring ones or ghawun).

Indeed, as a form of art - and all other art forms - poetry could be a very tricky, double-sided and devious business. As a means, rather than end, its legitimacy, or otherwise, depends on how and for what purposes it is used. Just as it can generate much goodness, it likewise can procure much harm. Still, there is much room for appropriate poetry and art in Islam and its civilisation. That is on condition that the divine criteria, which are clearly spelled out in the surah and elsewhere in the Qur'an, are duly fulfilled.

Architecture is also depicted in the surah as an effective means of communication and a canvas for expressing convictions and articulating preferences. The 'Ad and Thamud peoples, as well as Pharaoh, built enormous and sumptuous private and intuitional buildings. Those buildings were a sign of their leading the lives of extravagance in luxury and self-indulgence, putting forward extravagant claims for men's powers and material resources.

However, they were told to mend their ways and cultivate virtue instead, and to use their prowess for a greater and more authentic and sustainable good. Architecture is not only about the form. It is also, and substantially more, about utility, appropriate function, and spiritual as well as ethical considerations and goals. A truly great architecture is the one which is at peace and in harmony with the heavens and the earth and with their respective laws and tenets. It is the one that personifies virtue and promotes it, improving people's lives and making them more meaningful and 
better facilitated. This is a universal and transcendental architectural prescription that is applicable in every age, circumstance and condition.

There is a harmonious and synergistic relationship between art in general and architecture. Though diverging from one another at the plane of major functions, the two take inspiration from and complement each other's total meaning and performance. When all is said and done, architecture is a form of art. An excellent building is not only functional. It is also pleasant and can bring delight to its users. It contributes to consciously creating emotions and experiences through an expression of skill and imagination. Both art and architecture signify an aggregate of the worldview, values, form, function, configuration and communication.

Finally, the surah brings home the importance of reading and acting upon the signs (ayat) which permeate each and every aspect of God's creation, including the rich and colourful history of mankind. God's divine revelations - especially the final revelation, the Holy Qur'an - are also replete with signs. Furthermore, all forms of human productivity and creative engagement - comprising art and architecture are likewise to serve an ontological purpose and be transformed into human-made signs. They are to serve as an extension of the created and revealed signs (ayat) of God. They are to be integrated into the latter. The whole existence is to be thus rendered an infinite montage of signs that will incessantly and compellingly attest to the existence, greatness, wisdom and benevolence of the Creator and Master of the universe.

\section{References}

Adajian, T. 2005. On the prototype theory of concepts and the definition of art. Journal of Aesthetics and Art Criticism 63: 231-236. https://doi.org/10.1111/j.00218529.2005.00203.x

2012. The definition of art. https://plato.stanford.edu/entries/artdefinition/ \#TraDef (accessed 17 April 2018).

Ali, A.Y. 1990. The Holy Qur'an, English translation of the meanings and commentary. Madinah: King Fahd Holy Qur'an Printing Complex.

Asad, M. 1980. The message of the Quran. http://www.muhammad-asad.com/Message-ofQuran.pdf (accessed 10 April 2018).

Borgdorff, H. 2006. The debate on research in the arts. Bergen: Kunsthogskolen i Bergen.

Boroson, K. 2016. What is architecture: Art or science? https://www.kbarch.com/articles/ what-is-architecture-art-or-science (accessed 17 April 2018).

Al-Bukhari, Muhammad b. Isma'il. 1981. Sahih al-Bukhari. Beirut: Dar al-Fikr.

Caicco, G. 2005. Architectural ethics. In Encyclopaedia of Science, Technology and Ethics. https://www.encyclopedia.com/science/encyclopedias-almanacs-transcripts-andmaps/architectural-ethics (accessed 20 April 2018). 
Al-Faruqi, Isma'il. 1981. Islam and architecture. In Fine arts in Islamic civilization, ed. M.A.J. Beg, 99-117. Kuala Lumpur: The University of Malaya Press.

1995. Al-Tawhid: Its implications for thought and life. Herndon: International Institute of Islamic Thought.

Fields, D.W. 2000. Architecture in black. London: The Athlone Press.

Freely, J. and Burelli, A.R. 1996. Sinan. London: Thames and Hudson.

Hillenbrand, R. 1999. Islamic art and architecture. London: Thames and Hudson.

Hosey, L. 2016. Why architecture isn't art (and shouldn't be). https://www.archdaily.com/ 783412/why-architecture-isnt-art-and-shouldnt-be (accessed 17 April 2018).

Ibn Kathir, Abu al-Fida'. 2000. Tafsir al-Qur'an al- 'Azim. http://www.altafsir.com/Tafasir .asp? $\mathrm{tMadhNo}=1 \& \mathrm{tTafsirNo}=7 \& \mathrm{tSoraNo}=9 \& \mathrm{tAy} \mathrm{ahNo}=107 \& \mathrm{tDisplay}=\mathrm{yes}$ \&UserProfile $=0 \&$ LanguageId $=1$ (accessed 26 March 2018).

Ibn Khaldun, Abd al-Rahman. 1967. The Muqaddimah (Translated from Arabic by Franz Rosenthal). Princeton: Princeton University Press.

Izetbegovic, A. 1988. Islam Izmedju Istoka i Zapada (Islam between East and West). Beograd: Nova.

Lamya', al-Faruqi. 1985. Islam and art. Islamabad: National Hijra Council.

Le Corbusier. 1989. Towards a new architecture (Translated from the 13th French edition with an introduction by Frederick Etchelles). Oxford: Reed Educational and Professional Publishing Ltd.

Maududi, S. 1982. The meaning of the Qur'an. http://www.englishtafsir.com/Quran/9/ index.html (accessed 26 March 2018).

McNally, C. 2017. How does construction impact the environment? https://www.initiafy. com/blog/how-does-construction-impact-the-environment (accessed 20 April 2018).

Misra, A. 2010. Did the prophet or the companions partake in poetry? http://islamqa.org/ hanafi/seekersguidance-hanafi/31932 (accessed 17 April 2018).

Peterson, D. 2017. Poetry in pre-Islamic Arabia. http://www.patheos.com/blogs/ danpeterson/2017/10/poetry-pre-islamic-arabia.html (accessed 19 April 2018).

Al-Qurtubi, Muhammad. 1967. Al-Jami' li Ahkam al-Qur'an. http:/www.altafsir.com/ Tafasir.asp? $\mathrm{tMadhNo}=1 \& \mathrm{tTafsirNo}=5 \& \mathrm{tSoraNo}=9 \& \mathrm{tAyahNo}=108 \& \mathrm{tDisplay}$ $=$ yes $\&$ UserProfile $=0 \&$ LanguageId $=1$ (accessed 26 March 2018).

Ratna, M.R. 2015. Methods and techniques of Dr. Shawqi Dayf in the literary criticism. BEST: Journal of Humanities, Arts, Medicine and Sciences 1(1): 65-68.

Al-Razi, Fakhruddin. 1990. Mafatih al-Ghayb. http://www.altafsir.com/Tafasir.asp? $\mathrm{tMadhNo}=1 \& \mathrm{tTafsirNo}=4 \& \mathrm{tS}$ oraNo=9\& $\mathrm{tAyahNo}=108 \& \mathrm{tDisplay}=\mathrm{yes}$ $\&$ UserProfile $=0 \&$ LanguageId $=1$ (accessed 26 March 2018).

Al-Sabuni, Muhammad. 1981. Mukhtasar tafsir Ibn Kathir. Beirut: Dar al-Qur'an alKarim.

Al-Samahudi, 'Ali b. Ahmad. 1997. Wafa' al-Wafa. Beirut: Dar Ihya' al-Turath al-'Arabi. Seow, C.L. 2013. Job 1-21, interpretation and commentary. Michigan: William B. Eerdmans Publishing Company.

Al-Tabari, Ibn Jarir. 2013. Jami' al-Bayan fi Tafsir al-Qur'an. http://www.altafsir.com/ Tafasir.asp?tMadhNo=1\&tTafsirNo=1\&tSoraNo=9\&tAyahNo=107\&tDisplay $=$ yes $\&$ UserProfile $=0 \&$ Language $\mathrm{Id}=1$ (accessed 26 October 2018). 
Wan Razali, W.M. and Awang, J. 2016. Ibn Khaldun's Religionswissenschaft: Exploring the sources in the Muqaddimah. UMRAN: International Journal of Islamic and Civilizational Studies 4(1): 67-79. https://doi.org/10.11113/umran2017.4n1.133

Wasserman, B., Sullivan, P. and Palermo, G. 2000. Ethics and the practice of architecture. New York: John Wiley \& Sons Inc. 